\title{
Key Factors Influencing Sustainable Development of a Green Energy Industry in Taiwan
}

\author{
Wen-Chih Huang, ${ }^{1}$ Chiu-Hua Jhong, ${ }^{2}$ and Ji-Feng Ding ${ }^{3}$ \\ ${ }^{1}$ Department of Transportation Technology and Management, Kainan University, Taoyuan 338, Taiwan \\ ${ }^{2}$ Department of Harbor and River Engineering, National Taiwan Ocean University, Keelung 202, Taiwan \\ ${ }^{3}$ Department of Aviation and Maritime Transportation Management, Chang Jung Christian University, Tainan City 711, Taiwan
}

Correspondence should be addressed to Ji-Feng Ding; jfding@mail.cjcu.edu.tw

Received 25 September 2013; Accepted 11 November 2013

Academic Editor: Kim-Hua Tan

Copyright (C) 2013 Wen-Chih Huang et al. This is an open access article distributed under the Creative Commons Attribution License, which permits unrestricted use, distribution, and reproduction in any medium, provided the original work is properly cited.

\begin{abstract}
The main purpose of this paper was to apply the fuzzy analytic hierarchy process (FAHP) approach to explore key factors influencing the sustainable development of a green energy industry in Taiwan. Based on the literature and experts' opinions, a hierarchical structure with five assessment aspects and fifteen development factors was first constructed, and a FAHP algorithm model was then proposed. Finally, based on the AHP experts' questionnaires, we used the FAHP approach to evaluate the key factors. The results showed the following. (1) "Technology" is the most important aspect influencing sustainable development of green energy industry in Taiwan. (2) In order of relative importance, the top six key factors influencing sustainable development of green energy industry in Taiwan are "establishment of key technological capabilities," "degree of integration of relevant laws and regulations," "establishment of an industry chain," "key raw materials and production equipment," "protection of intellectual property," and "preferential purchase price rates and various subsidies," respectively.
\end{abstract}

\section{Introduction}

Due to the world economy's heavy dependence on fossil fuels during the past decades, the carbon dioxide emissions accompanying economic development have intensified the global greenhouse effect, and global warming, climate change, and ecological destruction have severely threatened human survival. As a result, the issue of sustainable development [16 ] is growing in importance, and the governments of many countries have made sustainable development one of their administrative focal points.

Addressing global warming and environmental changes, the December 2009 United Nations Climate Change Conference in Copenhagen targeted the issues of reducing dependence on fossil fuels, vigorously searching for alternative energy sources. The conclusions of this conference have inspired new thinking about research and development of a green energy industry. In view of the need for energy and sustainable development, the development of renewable, lowpollution, environmentally friendly green energy has become an important aspect of environmental protection and energy policies $[3,4,7-9]$.

Taiwan has few natural resources and must depend largely on imports for the energy needed for economic development. However, international energy supplies and energy prices are easily affected by shifts in the international situation, and changes in energy prices can exert a major influence on domestic industry and economic development. In view of the need to reduce Taiwan's dependence on imported energy and provide Taiwan with reliable energy supplies, the government believes that the development of a "green energy industry" [1] can attain a balance among acquisition of energy, economic development, and environmental protection, while transforming Taiwan into a low-carbon, ecological country.

In 2008, the government of Taiwan vowed to make energy conservation and carbon emissions reduction important administrative policies. All industries that are able to conserve energy and reduce carbon emissions can be considered by the government as links in the green energy industry chain. Apart from the low-carbon energy industry, energy 
conservation/carbon reduction industry, and the greenhouse gas reduction industry, the government's promotion of the green energy industry chiefly focuses on the renewable energy industry [1], including solar power, wind power, hydropower, geothermal power, biofuels, and hydrogen fuel cell industries. Nevertheless, the government and industry must overcome many development obstacles (such as excessively high investment costs and problems connected with development effectiveness, prices, technology, and markets) if Taiwan is to develop a green energy industry.

Because the development of a green energy industry has become an important part of the government's sustainable development and energy conservation/carbon reduction policies, the government must bear responsibility for the establishment of an environment in which a green energy industry can develop. In order to enhance the competitiveness of Taiwan's green energy industry and to help firms overcome relevant issues, it is necessary to analyze what developmental factors the green energy industry should possess and what developmental factors are essential. Because of this, in the face of a steadily growing green energy market, we must ask what key factors firms must consider when entering the green energy industry. This research issue is very worthy of in-depth investigation.

In summary, the main purpose of this paper is to analyze key factors influencing sustainable development of a green energy industry in Taiwan. This issue faces the qualitative characteristics of multiple factors questions and the inherently fuzzy nature of individuals' subjective views; it would be very difficult to express the importance of assessment factors in terms of precise values. Determining the importance of sustainable development factors constitutes a multiple criteria problem in which information is incomplete or imprecise and views may be subjective or endowed with linguistic characteristics. Hence, this study applies the fuzzy set theory [10] in conjunction with the AHP approach [11] to construct a fuzzy analytic hierarchy process (FAHP) approach, which can be used as a model enabling stakeholders to assess the key factors involved in sustainable development of green industries. The following section presents the preliminary assessment factors, and the third section described the method of FAHP approach. The fourth section consists of an empirical study, and the final section presents some conclusions.

\section{Preliminary Factors Facilitating the Development of a Green Energy Industry}

In order to understand factors needed for the development of a green energy industry, this study first gathered some key factors from the literature and obtained preliminary views concerning Taiwan's green energy development directions from interviews with experts and scholars. The study finally gleaned five major assessment aspects and 15 important developmental factors. The five aspects are technology, investment, government policy, environment, and market, and their characteristics are described in Table 1.

\section{Method}

The concepts and methods used in this paper are briefly introduced in this section.

3.1. Triangular Fuzzy Numbers and Algebraic Operations. In a universe of discourse $X$, a fuzzy subset $M$ of $X$ is defined by a membership function $f_{M}(x)$, which maps each element $x$ in $X$ to a real number in the interval $[0,1]$. The value of function $f_{M}(x)$ represents the grade of membership of $x$ in $M$.

A fuzzy number $M$ [18] in real line $\mathfrak{R}$ is a triangular fuzzy number if its membership function $f_{M}: \mathfrak{R} \rightarrow[0,1]$ is

$$
f_{M}(x)= \begin{cases}\frac{(x-c)}{(a-c)}, & c \leq x \leq a \\ \frac{(x-b)}{(a-b)}, & a \leq x \leq b \\ 0, & \text { otherwise }\end{cases}
$$

with $-\infty<c \leq a \leq b<\infty$. A triangular fuzzy number can be denoted by $(c, a, b)$.

In this paper, Zadeh's extension principle [10] is employed to perform algebraic operations involving fuzzy numbers. Let $M_{1}=\left(c_{1}, a_{1}, b_{1}\right)$ and $M_{2}=\left(c_{2}, a_{2}, b_{2}\right)$ be fuzzy numbers. The algebraic operations of any two fuzzy numbers $M_{1}$ and $M_{2}$ can be expressed as follows:

(1) fuzzy addition:

$$
M_{1} \oplus M_{2}=\left(c_{1}+c_{2}, a_{1}+a_{2}, b_{1}+b_{2}\right),
$$

(2) fuzzy subtraction:

$$
M_{1} \ominus M_{2}=\left(c_{1}-b_{2}, a_{1}-a_{2}, b_{1}-c_{2}\right),
$$

(3) fuzzy multiplication:

$$
\begin{gathered}
k \otimes M_{2}=\left(k c_{2}, k a_{2}, k b_{2}\right), \quad k \in \Re, k \geq 0, \\
M_{1} \otimes M_{2} \cong\left(c_{1} c_{2}, a_{1} a_{2}, b_{1} b_{2}\right), \quad c_{1} \geq 0, c_{2} \geq 0,
\end{gathered}
$$

(4) fuzzy division:

$$
\begin{gathered}
\left(M_{1}\right)^{-1}=\left(c_{1}, a_{1}, b_{1}\right)^{-1} \cong\left(\frac{1}{b_{1}}, \frac{1}{a_{1}}, \frac{1}{c_{1}}\right), \quad c_{1}>0, \\
M_{1} \varnothing M_{2} \cong\left(\frac{c_{1}}{b_{2}}, \frac{a_{1}}{a_{2}}, \frac{b_{1}}{c_{2}}\right), \quad c_{1} \geq 0, c_{2}>0 .
\end{gathered}
$$

3.2. Ranking Method. To match the FAHP algorithm developed in this paper and to solve the problem powerfully, the graded mean integration representation (GMIR) method, proposed by Chen and Hsieh [19], is employed to defuzzify the fuzzy weights.

Let $M_{i}=\left(c_{i}, a_{i}, b_{i}\right), i=1,2, \ldots, n$, be $n$ triangular fuzzy numbers. By the GMIR method, the GMIR value $R\left(M_{i}\right)$ of $M_{i}$ is

$$
R\left(M_{i}\right)=\frac{c_{i}+4 a_{i}+b_{i}}{6} .
$$

Suppose $R\left(M_{i}\right)$ and $R\left(M_{j}\right)$ are the GMIR values of $M_{i}$ and $M_{j}$, respectively. We define the following: 
TABLE 1: Preliminary factors facilitating the development of a green energy industry.

\begin{tabular}{|c|c|c|c|}
\hline $\begin{array}{l}\text { Assessment } \\
\text { aspects }\end{array}$ & $\begin{array}{l}\text { Development } \\
\text { factors }\end{array}$ & Explanation of development factors & References \\
\hline \multirow{3}{*}{$\begin{array}{l}\text { Technology } \\
\left(C_{1}\right)\end{array}$} & $\begin{array}{l}\text { Establishment } \\
\text { of key } \\
\text { technological } \\
\text { capabilities } \\
\left(C_{11}\right)\end{array}$ & $\begin{array}{l}\text { Key technologies are important elements in the development of factors of } \\
\text { production, and key technological capabilities constitute strategic assets. If key } \\
\text { technological systems can be integrated successfully, industrial cooperation } \\
\text { mechanisms can industrialize and commercialize key technologies, changing the } \\
\text { industry structure and enhancing competitive advantage. }\end{array}$ & {$[1,12]$} \\
\hline & $\begin{array}{l}\text { Protection of } \\
\text { intellectual } \\
\text { property }\left(C_{12}\right)\end{array}$ & $\begin{array}{l}\text { The protection of intellectual property rights will ensure that creators of intellectual } \\
\text { property can enjoy the fruits of their innovations and will encourage the creation of } \\
\text { even more intellectual property, which will have a positive effect on socioeconomic } \\
\text { development and allow other members of the public to benefit from the intellectual } \\
\text { property. The development of a green energy industry must rely on the patenting of } \\
\text { inventions to promote technological autonomy and ensure that companies can } \\
\text { securely transfer their technologies, facilitating the industry's development. }\end{array}$ & {$[1,4]$} \\
\hline & $\begin{array}{l}\text { Cultivation of } \\
\text { green energy } \\
\text { industry } \\
\text { manpower }\left(C_{13}\right)\end{array}$ & $\begin{array}{l}\text { Personnel possessing technical knowledge play an extremely important role in the } \\
\text { ceaseless process of innovation and improving competitiveness in the green energy } \\
\text { industry. Via the establishment of laboratory system mechanisms, the provision of a } \\
\text { secure environment can attract overseas manpower and ultimately enhance } \\
\text { international competitiveness. Upgrading the green energy industry in the future } \\
\text { must be accompanied by the constant training of industrial manpower, which will } \\
\text { support the industry's future development and promote the industry's sustainable } \\
\text { development. }\end{array}$ & {$[1,12]$} \\
\hline \multirow{3}{*}{$\begin{array}{l}\text { Investment } \\
\left(C_{2}\right)\end{array}$} & $\begin{array}{l}\text { Establishment } \\
\text { of an industry } \\
\text { chain }\left(C_{21}\right)\end{array}$ & $\begin{array}{l}\text { Many problems will emerge during the intensely competitive process of industrial } \\
\text { development. From a long-range perspective, only the establishment of an effective, } \\
\text { well-integrated industry chain can boost the effectiveness and strength of the } \\
\text { industry chain as a whole, enhancing the industry's competitive advantage. }\end{array}$ & {$[4,12]$} \\
\hline & $\begin{array}{l}\text { Key raw } \\
\text { materials and } \\
\text { production } \\
\text { equipment }\left(C_{22}\right)\end{array}$ & $\begin{array}{l}\text { Investment in the development of key raw materials is extremely important if it is } \\
\text { desired to produce superior green energy products. If Taiwan cannot provide an } \\
\text { adequate supply of key raw materials and elements, this will be equivalent to control } \\
\text { by foreign firms and will restrict the industry's future development. Conversely, if } \\
\text { key raw materials and production equipment can be marketed internationally, this } \\
\text { will boost the value of the industry's products and provide more employment } \\
\text { opportunities in the industry. }\end{array}$ & {$[4,8,12]$} \\
\hline & $\begin{array}{l}\text { Promotion of } \\
\text { relevant } \\
\text { investments in } \\
\text { the industry } \\
\left(C_{23}\right)\end{array}$ & $\begin{array}{l}\text { The green energy industry is a technology- and capital-intensive industry and } \\
\text { requires interdisciplinary manpower. In order to lengthen the green energy product } \\
\text { life cycle, firms must invest in the industry's suppliers, and the industry's } \\
\text { development must be well integrated, which will expand domestic industrial } \\
\text { activity and promote industrial investment, leading to a clustering effect and } \\
\text { enhancing the green energy industry's international competitiveness. }\end{array}$ & {$[1,4]$} \\
\hline \multirow[t]{2}{*}{$\begin{array}{l}\text { Government } \\
\text { policy }\left(C_{3}\right)\end{array}$} & $\begin{array}{l}\text { Degree of } \\
\text { integration of } \\
\text { relevant laws } \\
\text { and regulations } \\
\left(C_{31}\right)\end{array}$ & $\begin{array}{l}\text { If green energy industrial development laws and regulations can integrate the } \\
\text { perspectives of manufacturers, customers, and other interested parties and ensure } \\
\text { that all interested parties believe that the government's laws and regulations can } \\
\text { effectively promote the development of green energy industry, then interested } \\
\text { parties will be even more willing to invest in the development of green energy } \\
\text { products. In particular, when products are sold globally, testing and certification in } \\
\text { Taiwan should be consistent with international standards. And, to avoid restricting } \\
\text { the industry's development, the government should strive to integrate laws and } \\
\text { regulations while maintaining an emphasis on deregulation. }\end{array}$ & {$[1,12]$} \\
\hline & $\begin{array}{l}\text { Effective and } \\
\text { convenient } \\
\text { corporate } \\
\text { incentive } \\
\text { measures }\left(C_{32}\right)\end{array}$ & $\begin{array}{l}\text { When the firms in industry clusters form mutually beneficial relationships, relevant } \\
\text { economic factors of production (such as technology, manpower, information, and } \\
\text { funds) will accumulate continuously. When the government has effective and } \\
\text { convenient corporate encouragement measures, this will have a positive effect on } \\
\text { clustering of the industry and will enhance the competitiveness of the industry as a } \\
\text { whole. }\end{array}$ & {$[1,4,12]$} \\
\hline
\end{tabular}


TABle 1: Continued.

\begin{tabular}{|c|c|c|c|}
\hline $\begin{array}{l}\text { Assessment } \\
\text { aspects }\end{array}$ & $\begin{array}{l}\text { Development } \\
\text { factors }\end{array}$ & Explanation of development factors & References \\
\hline $\begin{array}{l}\text { Government } \\
\text { policy }\left(C_{3}\right)\end{array}$ & $\begin{array}{l}\text { Preferential } \\
\text { purchase price } \\
\text { rates and } \\
\text { various } \\
\text { subsidies }\left(C_{33}\right)\end{array}$ & $\begin{array}{l}\text { To encourage the development of zero-pollution green energy, government policies } \\
\text { must provide purchase prices offering sufficient incentive and must also provide } \\
\text { incentive measures (such as subsidies and tariff exemptions) in order to promote } \\
\text { the creation of a renewable energy market. }\end{array}$ & {$[1,3,4,8]$} \\
\hline \multirow{3}{*}{$\begin{array}{l}\text { Environment } \\
\left(C_{4}\right)\end{array}$} & $\begin{array}{l}\text { Establishment } \\
\text { of international } \\
\text { certification } \\
\text { laboratories } \\
\left(C_{41}\right)\end{array}$ & $\begin{array}{l}\text { In order to provide the green energy industry with comprehensive technical } \\
\text { support encompassing the areas of quality, performance, safety, and transactions } \\
\text { and thereby enhance the international competitive advantage of the industry and its } \\
\text { technology, companies must support the adoption of international certification } \\
\text { technology. The establishment of an international certification laboratory } \\
\text { framework can help companies to enhance quality, strengthen product quality and } \\
\text { differentiation, accelerate mass production and value-adding capacity, and boost } \\
\text { the industry's competitiveness. }\end{array}$ & {$[9,13]$} \\
\hline & $\begin{array}{l}\text { Shaping of the } \\
\text { green energy } \\
\text { environment; } \\
\text { creation of } \\
\text { demand }\left(C_{42}\right)\end{array}$ & $\begin{array}{l}\text { The government should shape an environment in which the green energy industry } \\
\text { can develop and create domestic and foreign demand. In the domestic market, the } \\
\text { government can expand the application of green energy products in public } \\
\text { development projects or increase its purchases of green energy products. As for } \\
\text { expansion of foreign markets, the signing of international accreditation and } \\
\text { certification protocols and mutual authorization, can reduce companies' trade costs, } \\
\text { enhancing the competitiveness of the green energy industry. }\end{array}$ & {$[1,3-5,12,14,15]$} \\
\hline & $\begin{array}{l}\text { Creating a } \\
\text { sustainable } \\
\text { development } \\
\text { environment for } \\
\text { green energy } \\
\left(C_{43}\right)\end{array}$ & $\begin{array}{l}\text { The core spirit of green energy is sustainability. Through the environmental } \\
\text { sustainability concept, the combination of environmental conservation and } \\
\text { education can induce relevant interested parties in the green industry chain (such as } \\
\text { manufacturers, consumers, and government) to collectively realize environmental } \\
\text { sustainability (in education, environmental protection, and transportation), } \\
\text { establishing a sustainable green energy environment. }\end{array}$ & {$[1,5,14,15]$} \\
\hline \multirow{3}{*}{ Market $\left(C_{5}\right)$} & $\begin{array}{l}\text { Identification } \\
\text { with green } \\
\text { market values } \\
\left(C_{51}\right)\end{array}$ & $\begin{array}{l}\text { Green marketing has arisen in the wake of green consumerism. In particular, in } \\
\text { international marketing activities, in order to promote the development of } \\
\text { international trade, it is also necessary to protect the environment. It is therefore } \\
\text { necessary to make consumers aware of the importance of green consumerism and } \\
\text { foster a consensus to protect the environment. These concepts will establish green } \\
\text { market values in the minds of consumers, give green energy products a superior } \\
\text { impression, and enhance companies' image. }\end{array}$ & {$[2,7,16]$} \\
\hline & $\begin{array}{l}\text { Size of market } \\
\text { and stability } \\
\left(C_{52}\right)\end{array}$ & $\begin{array}{l}\text { The size and stability of the consumer market are important factors affecting } \\
\text { whether green energy product sales channels can be developed. Because } \\
\text { government policy directions and consumer purchasing behavior can influence the } \\
\text { size of the green energy market and consumer confidence, there should be a balance } \\
\text { between green energy supply and demand as much as possible. }\end{array}$ & {$[6,12]$} \\
\hline & $\begin{array}{l}\text { Strengthening } \\
\text { economic } \\
\text { cooperation in } \\
\text { the international } \\
\text { market }\left(C_{53}\right)\end{array}$ & $\begin{array}{l}\text { The green energy industry is a global industry, and the industry and government } \\
\text { should therefore strive to resolve asymmetric trade barriers between trading } \\
\text { partners and strengthen firms understanding of foreign markets, which will help } \\
\text { firms to respond to and strengthen risk control, expand green energy products } \\
\text { market channels, and enhance domestic firms' ability to operate in international } \\
\text { markets. }\end{array}$ & {$[12,17]$} \\
\hline
\end{tabular}

(i) $M_{i}>M_{j} \Leftrightarrow R\left(M_{i}\right)>R\left(M_{j}\right)$,

(ii) $M_{i}<M_{j} \Leftrightarrow R\left(M_{i}\right)<R\left(M_{j}\right)$,

(iii) $M_{i}=M_{j} \Leftrightarrow R\left(M_{i}\right)=R\left(M_{j}\right)$.

3.3. FAHP Approach. The steps of the FAHP approach are described below.

Step 1 (establishment of a hierarchical structure). This study employs the hierarchical framework diagram shown in
Figure 1. In this framework, the problems lie on the Lth layer and consist of factors with a major influence on sustainable development of green energy industry. There are $k$ assessment aspects on the $L+1$ layer and $p+\cdots+q+\cdots+r$ development factors on the $L+2$ layer.

Step 2 (establishment of pairwise comparison matrices for development factors). Pairwise comparison of questionnaire results was employed to determine the experts' views of the relative importance of paired development factors. 


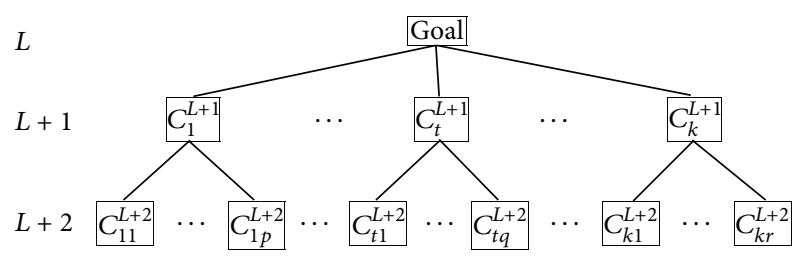

Figure 1: Hierarchical structure.

(1) Let $\delta_{i j}^{h}, h=1,2, \ldots, n$, be the relative importance assigned to any two assessment aspects $i$ and $j$ by expert $h$ on the $L+1$ layer. Then, the pairwise comparison matrix is defined as $\left[\delta_{i j}^{h}\right]_{k \times k}$.

(2) Let $\delta_{u v}^{h}, h=1,2, \ldots, n$, be the relative importance assigned to any two development factors $u$ and $v$ by expert $h$ on the $L+2$ layer. Then, the pairwise comparison matrix with respect to each assessment aspect, that is, $C_{1}^{L+1}, C_{t}^{L+1}, C_{k}^{L+1}$, is defined as $\left[\delta_{u v}^{h}\right]_{p \times p}$, $\left[\delta_{u v}^{h}\right]_{q \times q},\left[\delta_{u v}^{h}\right]_{r \times r}$.

Step 3 (establishing triangular fuzzy numbers). The generalized mean is a typical representation of many well-known averaging operations [20], including min, max, geometric mean, arithmetic mean, and harmonic mean. The min and max represent the lower and upper bounds of generalized means. In addition, the geometric mean is the most effective at representing the consensus views of multiple decision makers [11]. To aggregate all information generated by different averaging operations, we use the grade of membership to demonstrate their strength after considering all approaches. Triangular fuzzy numbers characterized through use of min, max, and geometric mean operations are therefore used to convey the views of all experts [21].

Let $\delta_{i j}^{h} \in[1 / 9,1 / 8, \ldots, 1 / 2,1] \cup[1,2, \ldots, 8,9], h=$ $1,2, \ldots, n, \forall i, j=1,2, \ldots, k$, be the relative importance assigned to any two assessment aspects $i$ and $j$ by expert $h$ on the $L+1$ layer. After integrating the views of all $n$ experts, the triangular fuzzy numbers can be expressed as

$$
\widetilde{M}_{i j}^{L+1}=\left(c_{i j}, a_{i j}, b_{i j}\right),
$$

where $c_{i j}=\min \left\{\delta_{i j}^{1}, \delta_{i j}^{2}, \ldots, \delta_{i j}^{n}\right\}, a_{i j}=\left(\prod_{h=1}^{n} \delta_{i j}^{h}\right)^{1 / n}$, and $b_{i j}=$ $\max \left\{\delta_{i j}^{1}, \delta_{i j}^{2}, \ldots, \delta_{i j}^{n}\right\}$.

We can integrate the views of all $n$ experts on the $L+2$ layer in the same way, so that the triangular fuzzy numbers can be expressed as

$$
\begin{array}{r}
\widetilde{M}_{u v}^{L+2}=\left(c_{u v}, a_{u v}, b_{u v}\right), \quad \forall u, v=1, \ldots, p ; \ldots ; \\
\forall u, v=1, \ldots, q ; \ldots ; \forall u, v=1, \ldots, r
\end{array}
$$

where $c_{u v}=\min \left\{\delta_{u v}^{1}, \delta_{u v}^{2}, \ldots, \delta_{u v}^{n}\right\}, a_{u v}=\left(\prod_{h=1}^{n} \delta_{u v}^{h}\right)^{1 / n}$, and $b_{u v}=\max \left\{\delta_{u v}^{1}, \delta_{u v}^{2}, \ldots, \delta_{u v}^{n}\right\}$.

Step 4 (constructing fuzzy positive reciprocal matrices). We use the integrated triangular fuzzy numbers to construct fuzzy positive reciprocal matrices. For the $L+1$ layer, the fuzzy positive reciprocal matrix can be expressed as

$$
M=\left[\widetilde{M}_{i j}^{L+1}\right]=\left[\begin{array}{cccc}
1 & \widetilde{M}_{12}^{L+1} & \cdots & \widetilde{M}_{1 k}^{L+1} \\
\frac{1}{\widetilde{M}_{12}^{L+1}} & 1 & \cdots & \widetilde{M}_{2 k}^{L+1} \\
\vdots & \vdots & \ddots & \vdots \\
\frac{1}{\widetilde{M}_{1 k}^{L+1}} & \frac{1}{\widetilde{M}_{2 k}^{L+1}} & \cdots & 1
\end{array}\right],
$$

where $\widetilde{M}_{i j}^{L+1} \otimes \widetilde{M}_{j i}^{L+1} \cong 1, \forall i, j=1,2, \ldots, k$.

The equations of the fuzzy positive reciprocal matrices on the $L+2$ layer can be obtained using an analogous and method.

Step 5 (calculation of the fuzzy weights of the fuzzy positive reciprocal matrices). Let $\widetilde{F}_{i}^{L+1} \cong\left(\widetilde{M}_{i 1}^{L+1} \otimes\right.$ $\left.\widetilde{M}_{i 2}^{L+1} \otimes \cdots \otimes \widetilde{M}_{i k}^{L+1}\right)^{1 / k}, \forall i=1,2, \ldots, k$, be the geometric mean of triangular fuzzy number of the $i$ th assessment aspect on the $L+1$ layer. The fuzzy weight of the $i$ th assessment aspect can then be expressed as

$$
\widetilde{W}_{i}^{L+1} \cong \widetilde{F}_{i}^{L+1} \otimes\left(\widetilde{F}_{1}^{L+1} \oplus \widetilde{F}_{2}^{L+1} \oplus \cdots \oplus \widetilde{F}_{k}^{L+1}\right)^{-1} .
$$

For convenience, the fuzzy weight is expressed as $\widetilde{W}_{i}^{L+1}=$ $\left(w_{i}^{c}, w_{i}^{a}, w_{i}^{b}\right)$. The equations of fuzzy weights on the $L+2$ layer can be obtained using an analogous and method.

Step 6 (defuzzifying the fuzzy weights to obtain crisp weights). To perform defuzzification in an effective manner, the GMIR method is used to defuzzify the fuzzy weights. Let $\widetilde{W}_{i}^{L+1}=\left(w_{i}^{c}, w_{i}^{a}, w_{i}^{b}\right), \forall i=1,2, \ldots, k$, be $k$ triangular fuzzy numbers. The GMIR of crisp weights $k$ can then be expressed as

$$
R\left(\widetilde{W}_{i}^{L+1}\right)=\frac{w_{i}^{c}+4 w_{i}^{a}+w_{i}^{b}}{6}, \quad \forall i=1,2, \ldots, k .
$$

The defuzzification of fuzzy weights on the $L+2$ layer can be performed using an analogous and method.

Step 7 (normalizing the crisp weights). To facilitate comparison of the relative importance of assessment aspects on different layers, the crisp weights are normalized and expressed as

$$
N W_{i}^{L+1}=\frac{R\left(\widetilde{W}_{i}^{L+1}\right)}{\sum_{i=1}^{k} R\left(\widetilde{W}_{i}^{L+1}\right)} .
$$

Step 8 (calculating the integrated weights for each layer). Let $N W_{i}^{L+1}$ and $N W_{u}^{L+2}$ be the normalized crisp weights on the $L+1$ and $L+2$ layers. Then, one has the following.

(1) The integrated weights of each assessment aspect on the $L+1$ layer are

$$
I W_{i}^{L+1}=N W_{i}^{L+1}, \quad \forall i=1,2, \ldots, k .
$$


(2) The integrated weights of each development factor on the $L+2$ layer are

$$
\begin{array}{r}
I W_{u}^{L+2}=N W_{i}^{L+1} \times N W_{u}^{L+2}, \quad \forall i=1,2, \ldots, k ; \\
\forall u=1, \ldots, p ; \ldots ; \forall u=1, \ldots, q ; \ldots ; \forall u=1, \ldots, r .
\end{array}
$$

\section{Empirical Study}

In this section, an empirical study for evaluating key factors influencing sustainable development of a green energy industry in Taiwan is surveyed as follows.

4.1. Data Collection. The survey performed in this study sought to assess the relative importance of factors needed for the development of a green energy industry in Taiwan and to determine the key factors needed for a green energy industry to develop. The study issued an AHP questionnaire to industry personnel, government representatives in charge of energy policy, and university professors studying the green energy industry.

An AHP questionnaire with five assessment aspects and fifteen development factors was used to compile the pairwise comparison matrices of each layer and express the relative importance of each development factor. To check whether the expressions/words were clear or important questions were missed, some scholars were invited to pretest the AHP questionnaire. Finally, two rounds of corrections based on questionnaire design principles were carefully performed, and the final AHP questionnaire was completed.

The surveys were completed through e-mails, phone calls, and in-person interviews conducted by the authors. The returned questionnaires were checked to determine whether the consistency index (CI) of each matrix of every layer was lower than 0.1 [11]. When the CI value of a matrix is higher than 0.1, this implies that the respondent had made an inconsistent pairwise comparison of two assessment aspects (or development factors). To prevent the occurrence of errors, the authors helped such respondents to correct their judgments until the CI value of each matrix was lower than 0.1 .

A total of 32 questionnaires were distributed and 31 were recovered, for a recovery rate of $97 \%$. Since the AHP questionnaire in this study was an expert questionnaire, Robbins recommendation that 5-7 experts are ideally required in studies of group decision-making questions suggests that the valid recovered questionnaires in this study provided representative views [22].

4.2. Results. In our case, with five assessment aspects and fifteen development factors, there were six $(1+5)$ pairwise comparison matrices to compile. The authors use five assessment aspects $\left(C_{1}-C_{5}\right)$ from the thirty-one valid questionnaires as an example to illustrate the computational procedures used in the FAHP approach. The other five pairwise comparison matrices are omitted by reasoning of analogy. The computational process and empirical results are shown as follows.
Step 1 (constructing a fuzzy positive reciprocal matrix). The authors used relative importance data from the thirty-one valid questionnaires to compile a pairwise comparison matrix and then transformed this data into triangular fuzzy numbers through geometric mean method. We then employed these triangular fuzzy numbers to construct a fuzzy positive reciprocal matrix. The fuzzy positive reciprocal matrix for the assessment aspects layer $\left(C_{1}-C_{5}\right)$ is shown in Table 2 .

Step 2 (calculating the fuzzy weights of the fuzzy positive reciprocal matrix). In keeping with Step 5 of the FAHP approach, the geometric means of the triangular fuzzy number $\left(\widetilde{F}_{i}^{L+1}\right)$ and the fuzzy weights $\left(\widetilde{W}_{i}^{L+1}\right)$ of five assessment aspects are as shown in Table 3.

Step 3 (defuzzifying the fuzzy weights and normalizing the crisp weights). Using Step 6 of the FAHP approach, the fuzzy weights can be defuzzified by the GMIR method to obtain the crisp weights $\left(R\left(\widetilde{W}_{i}^{L+1}\right)\right)$. Then, using Step 7 of the FAHP approach, we can obtain the normalized weights $\left(N W_{i}^{L+1}\right)$. The results are as shown in Table 4.

Step 4 (calculation of the integrated weights). After the encoding of the valid recovered questionnaires and combining the experts' views, this study used the FAHP procedures described in Section 3.3 to derive the relative weights of the development factors at each level, which enabled us to rank the assessment aspects and development factors in terms of relative importance (see Table 5).

The findings are described as follows.

(1) "Technology," ranking 1, is the most important aspect influencing sustainable development of a green energy industry in Taiwan. "Government policy," "investment," and "market" are ranked in the second, third, and fourth places. "Environment" is the lowest ranked. Although these assessment aspects can still be ranked in order of precedence, the fact that "technology," "government policy," and "investment" all had weights in the range of $0.22-0.25$ indicates that the experts viewed these three aspects as having roughly the same importance. In contrast, the weights of the aspects "markets" and "shaping the environment" were approximately 0.15 , which indicates that the experts considered these two aspects to be more or less equal in importance. On the whole, the experts felt that "technology," "government policy," and "investment" are the most important aspects connected with the development of a green energy industry.

(2) For the "technology" aspect by the normalized weights, the "establishment of key technological capabilities" is the critical development factor. For the "investment" aspect, the "establishment of an industry chain" is the critical development factor. For 
TABLE 2: Fuzzy positive reciprocal matrix for four risk aspects.

\begin{tabular}{cccccc}
\hline & $C_{1}$ & $C_{2}$ & $C_{3}$ & $C_{4}$ & $C_{5}$ \\
\hline$C_{1}$ & $(1,1,1)$ & $(0.167,2.949,9)$ & $(0.167,0.929,9)$ & $(0.25,1.758,7)$ & $(0.25,1.506,9)$ \\
$C_{2}$ & $(0.111,0.339,6)$ & $(1,1,1)$ & $(0.143,1.119,9)$ & $(0.2,1.351,9)$ & $(0.2,1.279,9)$ \\
$C_{3}$ & $(0.111,1.076,6)$ & $(0.111,0.894,7)$ & $(1,1,1)$ & $(0.333,2.835,9)$ & $(0.25,2.838,9)$ \\
$C_{4}$ & $(0.143,0.569,4)$ & $(0.111,0.740,5)$ & $(0.111,0.353,3)$ & $(1,1,1)$ & $(0.143,1.580,8)$ \\
$C_{5}$ & $(0.111,0.664,4)$ & $(0.111,0.782,5)$ & $(0.111,0.352,4)$ & $(0.125,0.633,7)$ & $(1,1,1)$ \\
\hline
\end{tabular}

TABLE 3: Geometric means of triangular fuzzy number and fuzzy weights.

\begin{tabular}{lccccc}
\hline & $i=1$ & $i=2$ & $i=3$ & $i=4$ & $i=5$ \\
\hline$\widetilde{F}_{i}^{L+1}$ & $(0.281,1.486,5.515)$ & $(0.229,0.919,5.348)$ & $(0.253,1.506,5.086)$ & $(0.191,0.748,3.438)$ & $(0.177,0.650,3.545)$ \\
$\widetilde{W}_{i}^{L+1}$ & $(0.012,0.280,4.882)$ & $(0.010,0.173,4.734)$ & $(0.011,0.284,4.502)$ & $(0.008,0.141,3.043)$ & $(0.008,0.122,3.138)$ \\
\hline
\end{tabular}

TABLE 4: Defuzzified and normalized weights of the five assessment aspects.

\begin{tabular}{lccccc}
\hline & $C_{1}$ & $C_{2}$ & $C_{3}$ & $C_{4}$ & $C_{5}$ \\
\hline $\begin{array}{l}\text { Defuzzified weights } \\
\left(R\left(\widetilde{W}_{i}^{L+1}\right)\right)\end{array}$ & 1.002 & 0.906 & 0.941 & 0.603 & 0.606 \\
$\begin{array}{l}\text { Normalized weights } \\
\left(N W_{i}^{L+1}\right)\end{array}$ & 0.247 & 0.223 & 0.232 & 0.1485 & 0.1495 \\
\hline
\end{tabular}

the "government policy" aspect, the "degree of integration of relevant laws and regulations" is the critical development factor. For the "environment" aspect, the "establishment of international certification laboratories" is the critical development factor. For the "market" aspect, the "identification with green market values" is the critical development factor.

(3) Daniel feels that most industries possess from two to six key elements [23] that determine success and a company that wishes to be successful must apply particular effort to these elements. Because of this, this study took $6.7 \%$ of the total weights of all 15 development factors as a threshold for selection of the most important criteria. As a consequence, this study employed the six of the 15 development factors that met this condition as the key factors affecting sustainable development of the green energy industry. The total weight of these factors was $54.27 \%$ (approximately 6/11). The results show that the top six key factors influencing sustainable development of a green energy industry in Taiwan are "establishment of key technological capabilities," "degree of integration of relevant laws and regulations," "establishment of an industry chain," "key raw materials and production equipment," "protection of intellectual property," and "preferential purchase price rates and various subsidies," respectively.

4.3. Discussions. The following is a discussion of the six key factors thought to be most closely connected with the development of a green energy industry.

4.3.1. Establishment of Key Technological Capabilities. In the eyes of the experts, this assessment factor is the most important factor, if Taiwan wishes to develop a green energy industry, and also represents strategic assets that Taiwan must establish and maintain when developing a green energy industry. Furthermore, the industry will have a greater competitive advantage when Taiwan can effectively provide key technical knowledge systems. Because of this, in the process of green energy industry development, the establishment of key technologies can increase the industry's competitive ability, enhance product quality or yield rate, and reduce production costs. Apart from this, because the green energy industry is an emerging industry, it is evolving rapidly, and the acquisition of key technological capabilities is therefore urgent to the industry's development. In the development of this emerging industry, Taiwan must shed its traditional role as a contract manufacturing specialist, while relying on national science and technology development programs to develop key technological capabilities needed for the industry's upgrading, which will ensure its profitability and international competitiveness.

4.3.2. Degree of Integration of Relevant Laws and Regulations. Because the green energy industry's supply chain includes several industries (such as the renewable energy industry, low-carbon energy industry, and energy conservation/carbon reduction industry) and green energy products of these industries can be sold on a global basis, government policies, laws, regulations, procedures, and decisions should be made as transparent, consistent, and effective as possible, which will ensure that interested parties connected with the industry can obtain needed information and procedures within the shortest possible time, while boosting efficiency and minimizing unnecessary procedures and expenses. Apart from this, the government should accelerate the easing of domestic laws and regulations in order to facilitate consistency with international standards, while also establishing a wellintegrated interdisciplinary industry development environment and promoting international cooperation, which will help eliminate barriers to entry into overseas markets.

4.3.3. Establishment of an Effective Industry Chain. Establishment of adequate infrastructure and an integrated industry structure will be necessary to the realization of a green energy industry. As a result, the availability of factors such 
TABLE 5: The normalized weights and integrated weights of each layer.

\begin{tabular}{|c|c|c|c|c|}
\hline $\begin{array}{l}\text { Assessment } \\
\text { aspects }\end{array}$ & $\begin{array}{c}\text { Normalized/integrated } \\
\text { weights }(A)\end{array}$ & Development factors & $\begin{array}{l}\text { Normalized } \\
\text { weights }(B)\end{array}$ & $\begin{array}{l}\text { Integrated weights } \\
\qquad(C)=(A) *(B)\end{array}$ \\
\hline \multirow{3}{*}{ Technology $\left(C_{1}\right)$} & \multirow{3}{*}{$0.247(1)$} & Establishment of key technological capabilities $\left(C_{11}\right)$ & $0.470(1)$ & $0.1161(1)$ \\
\hline & & Protection of intellectual property $\left(C_{12}\right)$ & $0.318(2)$ & $0.0785(5)$ \\
\hline & & $\begin{array}{l}\text { Cultivation of green energy industry manpower } \\
\left(C_{13}\right)\end{array}$ & $0.212(3)$ & $0.0524(11)$ \\
\hline \multirow{3}{*}{ Investment $\left(C_{2}\right)$} & \multirow{3}{*}{$0.223(3)$} & Establishment of an industry chain $\left(C_{21}\right)$ & $0.428(1)$ & $0.0954(3)$ \\
\hline & & Key raw materials and production equipment $\left(C_{22}\right)$ & $0.355(2)$ & $0.0792(4)$ \\
\hline & & $\begin{array}{l}\text { Promotion of relevant investments in the industry } \\
\left(C_{23}\right)\end{array}$ & $0.217(3)$ & $0.0484(12)$ \\
\hline \multirow{3}{*}{$\begin{array}{l}\text { Government } \\
\text { policy }\left(C_{3}\right)\end{array}$} & \multirow{3}{*}{$0.232(2)$} & $\begin{array}{l}\text { Degree of integration of relevant laws and } \\
\text { regulations }\left(C_{31}\right)\end{array}$ & $0.420(1)$ & $0.0974(2)$ \\
\hline & & $\begin{array}{l}\text { Effective and convenient corporate incentive } \\
\text { measures }\left(C_{32}\right)\end{array}$ & $0.252(3)$ & $0.0585(7)$ \\
\hline & & $\begin{array}{l}\text { Preferential purchase price rates and various } \\
\text { subsidies }\left(C_{33}\right)\end{array}$ & $0.328(2)$ & $0.0761(6)$ \\
\hline \multirow{3}{*}{$\begin{array}{l}\text { Environment } \\
\left(C_{4}\right)\end{array}$} & \multirow{3}{*}{$0.1485(5)$} & $\begin{array}{l}\text { Establishment of international certification } \\
\text { laboratories }\left(C_{41}\right)\end{array}$ & $0.388(1)$ & $0.0576(8)$ \\
\hline & & $\begin{array}{l}\text { Shaping of the green energy environment; creation } \\
\text { of demand }\left(C_{42}\right)\end{array}$ & $0.365(2)$ & $0.0542(10)$ \\
\hline & & $\begin{array}{l}\text { Creating a sustainable development environment for } \\
\text { green energy }\left(C_{43}\right)\end{array}$ & $0.247(3)$ & $0.0367(15)$ \\
\hline \multirow{3}{*}{ Market $\left(C_{5}\right)$} & \multirow{3}{*}{$0.1495(4)$} & Identification with green market values $\left(C_{51}\right)$ & $0.368(1)$ & $0.050(9)$ \\
\hline & & Size of market and stability $\left(C_{52}\right)$ & $0.319(3)$ & $0.0477(13)$ \\
\hline & & $\begin{array}{l}\text { Strengthening economic cooperation in the } \\
\text { international market }\left(C_{53}\right)\end{array}$ & $0.313(2)$ & $0.0468(14)$ \\
\hline
\end{tabular}

Numbers in parentheses are ranks.

as technology, funds, manpower, appropriate government policies, and integration of resources will expand opportunities for green products via the establishment of a valueadding industry chain and development of highly differentiated green energy products. Because the green energy industry faces high $\mathrm{R} \& \mathrm{D}$, mass production, and other costs during the initial period, it must rely on product design improvements and clustering of up-, mid-, and downstream industry chain segments to steadily reduce costs. Apart from clarifying the mutual relationships of different industries during the development process, the establishment of an effective green energy industry chain will consequently also facilitate integration of the industry's raw materials supply, manufacturing, and market demand levels. Furthermore, in order to stimulate the development of enterprises connected with the industry and thereby bring about closer linkage of the industry chain, which will enhance product added value, facilitate development of new overseas markets, and strengthen the competitiveness of green energy products, the government must help the industry chain develop various green energy product sales channels.

4.3.4. Key Raw Materials and Production Equipment. Production processes will require advanced materials and energy-conserving equipment if the green energy industry is to develop low-carbon, high-value fuel systems. However, because foreign green energy equipment suppliers have a lock on process design and production equipment, domestic firms have little room in which to develop equipment on their own. If individual companies cannot independently develop large energy conservation, low-carbon equipment, it is recommended that green energy industry parks implement energy integration plans aimed at increasing the energy utilization rate and easily the energy conservation equipment investment burden borne by individual firms. In addition, the green energy industry should strive to reduce carbon costs and enhance the efficiency of production processes in order to achieve the goal of lower production costs. At the same time, the industry should seek to establish green, low-carbon product brands, and the products bearing these brands should comply with the green energy product environmental sustainability requirements of the leading countries, while this will also promote attainment of Taiwan's economic development, energy conservation, and hazardous substance discharge reduction policy goals.

4.3.5. Protection of Intellectual Property Rights. The green energy industry possesses many patents protecting key technologies. These intellectual property rights require legal protection, and application for patent rights can reduce the risk of infringement. The ultimate goal of the intellectual property rights system is to encourage economic, cultural, and technological innovation and continuing development, 
and creators and inventors are thus granted intellectual property rights subject to protection. Because the protection of intellectual property rights is a crucial precondition to industrial development, the government should create a system for the utilization and protection of high-value patents, while training personnel knowledgeable in intellectual property practice. The protection of intellectual property will promote the establishment of a "knowledge demand market" worthy of the name, consolidate the nation's intellectual property knowledge base, and fulfill society's responsibility to respect intellectual property rights.

4.3.6. Subsidized Purchase Prices and Various Subsidies. Because Taiwan's green energy market is still in the preliminary development stage, many of the most common forms of renewable energy (such as solar and wind power) cannot reach the minimum level of economies of scale due to excessively high production costs and are therefore dependent on government subsidies, which can promote both expansion of supply and increased application by users. For instance, "renewable energy wholesale power purchase rates" drafted on the basis of the Statute on the Development of Renewable Energy and announced by the government in 2010 provide the 20-year guaranteed purchase of solar power at the rates of NT\$11.1-12.9 per kWh. This measure has induced the establishment of numerous large solar generating facilities. Although this has encouraged the establishment of a solar power industry, subsidies of this kind are a major fiscal burden on the government, and the fact that other types of green energy firms (such as wind power and biomass energy firms) do not receive such generous subsidies has caused firms in other green energy fields to question the fairness and reasonableness of current renewable energy subsidies. Furthermore, since the wholesale power purchase prices determined by the government must take factors such as development costs, recovery schedule, and the industry's economic effectiveness into consideration, the government should provide sufficient investment incentives, subsidized purchase prices, and various other subsidies in order to ensure favorable conditions for the development of the industry. In summary, in order to expand the green energy industry, the government's subsidized power rates and various subsidies should embody the principles of fairness and reasonableness. In order to promote green energy opportunities, substantive incentive methods should reflect the experience gained by the leading countries, encourage reasonable return on investment, fixed recovery schedules, and technological progress, while allowing the progressive reduction of subsidized purchase fee rates.

\section{Conclusions}

Driven by the global trend toward sustainable development, the green energy industry is attracting considerable attention worldwide. Due to Taiwan's relatively scarce natural resources and high dependence on imported energy, to ensure a reliable energy supply, the government has adopted the development of a green energy industry as a policy tool for achieving sustainable development, energy conservation, and reduction in carbon emissions. Nevertheless, the green energy industry faces many developmental roadblocks that can be overcome only through the concerted efforts of government and industry. The chief goal of this paper is consequently to explore factors influencing the development of a green energy industry in Taiwan, as well as to analyze key factors affecting the development of a green energy industry via the views of experts in government, industry, and academia.

The study's empirical analysis employed an AHP expert questionnaire to systematically assess the importance weights of developments factors and obtained the following results.

(1) There are three important assessment aspects"technology," "government policy," and "investment"-influencing sustainable development of green energy industry in Taiwan.

(2) The top six key factors influencing sustainable development of green energy industry in Taiwan are "establishment of key technological capabilities," "degree of integration of relevant laws and regulations," "establishment of an industry chain," "key raw materials and production equipment," "protection of intellectual property," and "preferential purchase price rates and various subsidies," respectively.

In addition, this study provides the following recommendations for government and industry, concerning possible follow-up research.

(1) Recommendations for the government are as follows. The development of a green energy industry is a worldwide trend, and the government can play an important role in the development of this emerging industry. In the future, the government can adopt green energy product standards and certification systems consistent with international norms, expand the size of the industry, promote systems integration, and provide assistance in the form of financing loans, product purchases, and promotional measures.

(2) Recommendations for the industry are as follows. Because the industry cannot depend entirely on government policy to drive its development, the industry must also focus on such major issues as recruiting and training key technological personnel, international technological interchange, efforts to stimulate consumer demand for green energy products, and international product marketing.

(3) Recommendations concerning follow-up research are as follows. Future research can collect more data on and further investigate such issues as the globalization of green energy product standards and certification systems, efforts to expand the industry, assistance to firms in establishing their own technological indicators, and loan financing for the green energy industry and the developing strategies. In addition, this study collected the views of various different parties during the process of determining assessment factors, which should meet the requirement for thoroughness. 
Nevertheless, statistical testing of the exclusivity and independence of the various assessment factors was perhaps insufficiently thorough. We therefore recommend that future research on this subject provide a clearer account of the relationships between individual assessment factors, which will facilitate further analysis of the key factors influencing the development of the green energy industry.

\section{Acknowledgments}

The authors would like to thank two anonymous referees for their excellent comments and valuable advice on this paper.

\section{References}

[1] M. S. Hsua and F. J. Linb, “The developing strategy of green energy industry cluster-a case study of the solar photoelectric industry in Taiwan," Procedia-Social and Behavioral Sciences, vol. 40, pp. 165-173, 2012.

[2] H. Saria and Hasnelly, "Factors determining green companies performance in Indonesia: a conceptual model," ProcediaSocial and Behavioral Sciences, vol. 57, pp. 518-523, 2012.

[3] T. Mezher, G. Dawelbait, and Z. Abbas, "Renewable energy policy options for Abu Dhabi: drivers and barriers," Energy Policy, vol. 42, pp. 315-328, 2012.

[4] P. D. Lund, "Effects of energy policies on industry expansion in renewable energy," Renewable Energy, vol. 34, no. 1, pp. 53-64, 2009.

[5] M. A. Cohen and M. P. Vandenbergh, "The potential role of carbon labeling in a green economy," Energy Economics, vol. 34, pp. S53-S63, 2012.

[6] Y. Matsuo, A. Yanagisawa, and Y. Yamashita, "A global energy outlook to 2035 with strategic considerations for Asia and Middle East energy supply and demand interdependencies," Energy Strategy Reviews, vol. 2, no. 1, pp. 79-91, 2013.

[7] B. Low, Y. Tang, and M. Medhekar, "Green power electricity, public policy and disjointed incrementalism," Journal of Business Research, vol. 65, no. 6, pp. 802-806, 2012.

[8] F. C. Menz, "Green electricity policies in the United States: case study," Energy Policy, vol. 33, no. 18, pp. 2398-2410, 2005.

[9] A. Lorenzoni, "The Italian Green Certificates market between uncertainty and opportunities," Energy Policy, vol. 31, no. 1, pp. 33-42, 2003.

[10] L. A. Zadeh, "Fuzzy sets," Information and Control, vol. 8, no. 3, pp. 338-353, 1965.

[11] T. L. Saaty, The Analytic Hierarchy Process, McGraw-Hill, New York, NY, USA, 1980.

[12] E. Heo, J. Kim, and K.-J. Boo, "Analysis of the assessment factors for renewable energy dissemination program evaluation using fuzzy AHP," Renewable and Sustainable Energy Reviews, vol. 14, no. 8, pp. 2214-2220, 2010.

[13] L. Nielsen and T. Jeppesen, "Tradable Green Certificates in selected European countries-overview and assessment," Energy Policy, vol. 31, no. 1, pp. 3-14, 2003.

[14] J. Hua, Y.-H. Wu, and P.-F. Jin, "Prospects for renewable energy for seaborne transportation-Taiwan example," Renewable Energy, vol. 33, no. 5, pp. 1056-1063, 2008.

[15] D. Furchtgott-Roth, "The elusive and expensive green job," Energy Economics, vol. 34, pp. S43-S52, 2012.
[16] L. Bird, R. Wüstenhagen, and J. Aabakken, "A review of international green power markets: recent experience, trends, and market drivers," Renewable and Sustainable Energy Reviews, vol. 6, no. 6, pp. 513-536, 2002.

[17] M. A. Cole, R. J. R. Elliott, and K. Shimamoto, "Why the grass is not always greener: the competing effects of environmental regulations and factor intensities on US specialization," Ecological Economics, vol. 54, no. 1, pp. 95-109, 2005.

[18] D. Dubois and H. Prade, "Operations on fuzzy numbers," The International Journal of Systems Science, vol. 9, no. 6, pp. 613626, 1978.

[19] S. H. Chen and C. H. Hsieh, "Representation, ranking, distance, and similarity of L-R type fuzzy number and application," Australian Journal of Intelligent Information Processing Systems, vol. 6, no. 4, pp. 217-229, 2000.

[20] G. L. Klir and B. Yuan, Fuzzy Sets and Fuzzy Logic Theory and Application, Prentice-Hall, New York, NY, USA, 1995.

[21] T. H. Hsu, "The fuzzy analytic hierarchy process," Journal of the Chinese Fuzzy Systems, vol. 4, no. 1, pp. 59-72, 1998.

[22] S. P. Robbi, Management, Prentice-Hall, Upper Saddle River, NJ, USA, 1994.

[23] R. D. Daniel, "Management information crisis," Harvard Business Review, vol. 39, no. 5, pp. 111-121, 1961. 


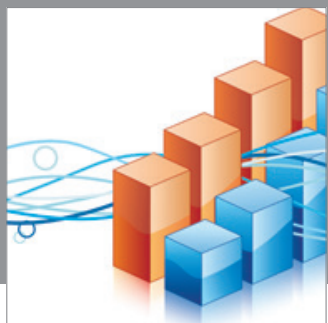

Advances in

Operations Research

mansans

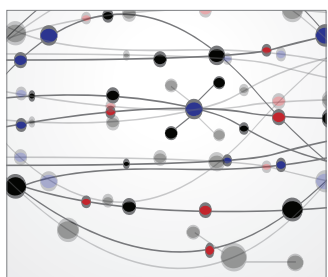

The Scientific World Journal
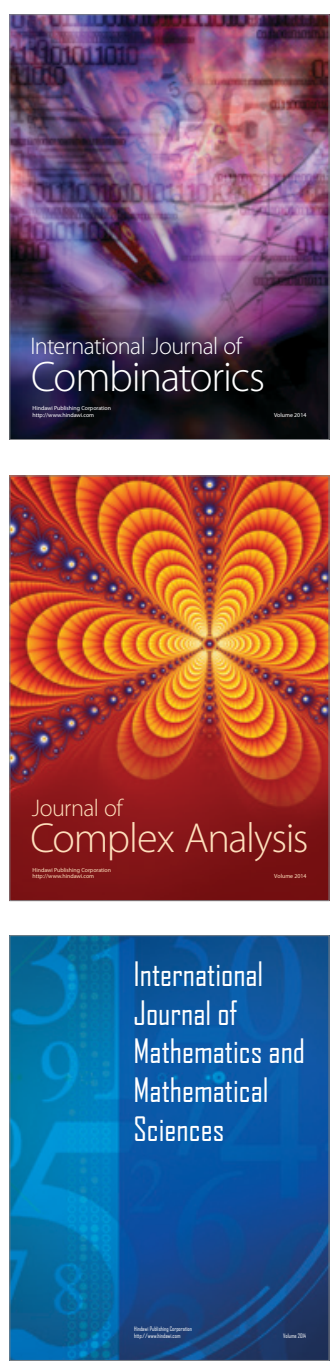
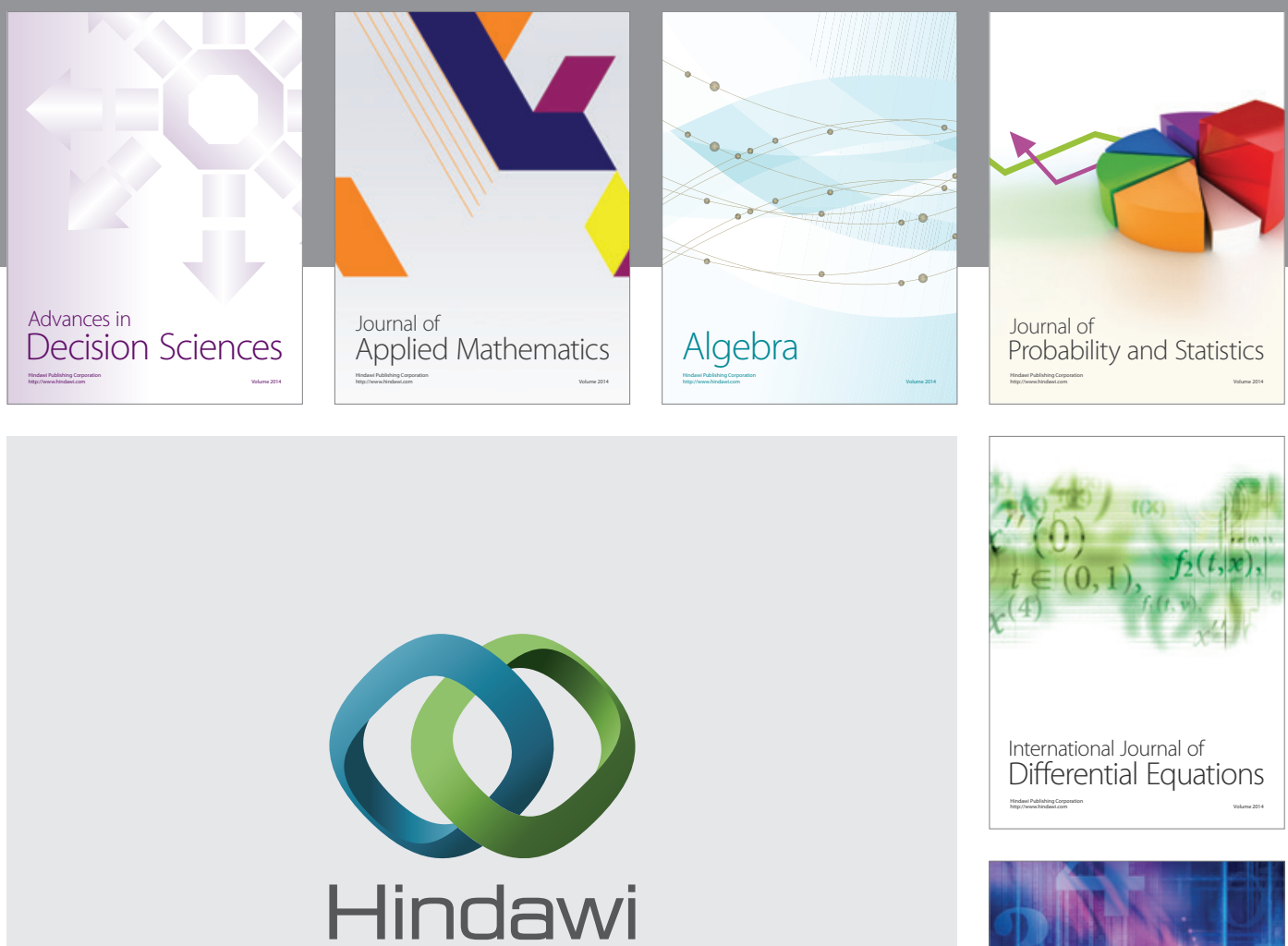

Submit your manuscripts at http://www.hindawi.com
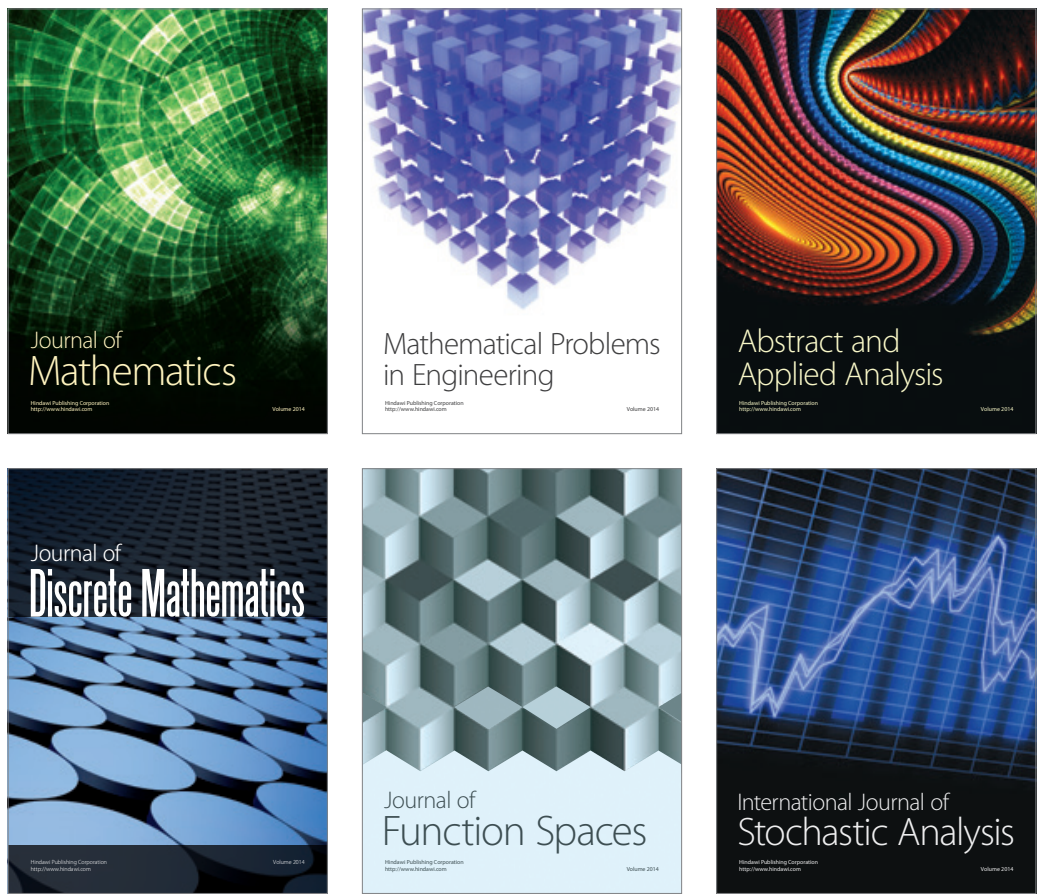

Journal of

Function Spaces

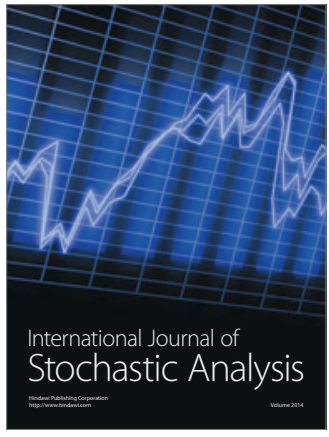

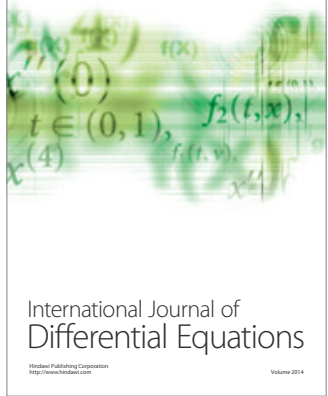
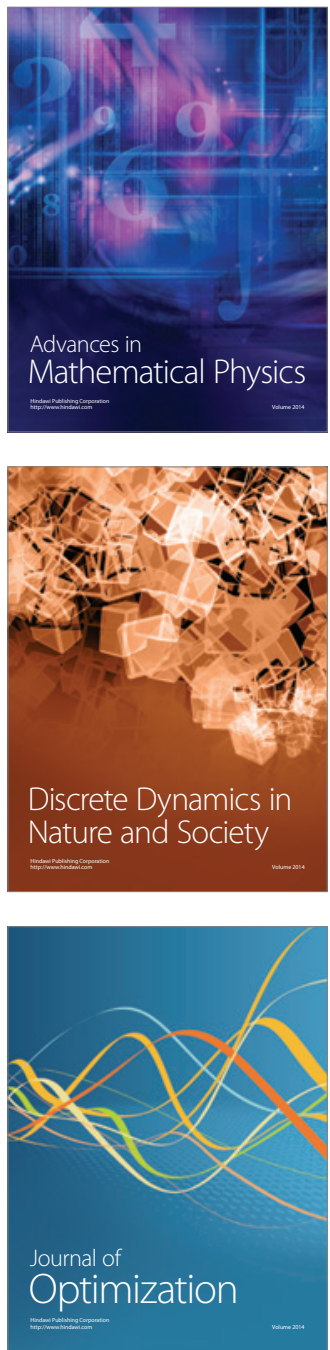